\title{
Feeding ecology of the siluriform Pimelodella laticeps Eigenmann, 1917 in a Pampean stream from Argentina
}

\author{
Mirta L. GARCÍA ${ }^{1}$, Lía C. SOLARI ${ }^{2} \&$ Javier R. GARCÍA DE SOUZA² \\ ${ }^{1}$ División Zoología Vertebrados, Facultad de Ciencias Naturales y Museo, Universidad Nacional de La Plata. \\ mgarcia@conicet.gov.ar. ${ }^{2}$ Instituto de Limnología "Dr. Raúl A. Ringuelet” (ILPLA, CONICET-UNLP). \\ Boulevard 120 y 62, N 1460 . CC: 712. (1900) La Plata, Buenos Aires, Argentina. Tel: (54-0221) 422-2775 (int. \\ 32, 41). E-mail: solari@ilpla.edu.ar; javiergds@ilpla.edu.ar
}

\begin{abstract}
Pimelodella laticeps Eigenmann, 1917 is the most abundant siluriform in the El Pescado Stream, located in the depressed region known as pampean region (Buenos Aires, Argentina). To characterize its feeding habits in this environment, we analyzed the dietary contents on seasonal samplings from May 1991 through August 1993. To evaluate the relative contribution of the different dietary components, the index of relative importance (IRI) was used. Pimelodella laticeps preferred sectors with aquatic macrophytes, and predated mainly on organisms from the periphytic and benthic communities. The main food was cyclopoid copepods, which taxa usually have littoral or benthic habitats, and only to a lesser extent are components of the plankton community. The planktonic organisms available in the environment were analyzed by the Olmstead-Tukey-test, which diagram indicated that the dominant items were copepods, ostracods, and chironomids. Chydorid cladocerans, harpacticoid copepods, mayfly larvae, and amphipods also became dominant but less frequently. To understand the feeding strategies of $P$. laticeps, the fish diet was compared with the available plankton as analyzed by a nonparametric multivariate analysis (permutation-based one-way ANOSIM). Pimelodella laticeps consumed almost no phytoplankton, while the discriminating items from the latter assemblage were identified as having high values in the environment.
\end{abstract}

Key words: : Feeding habits, gray catfish, dietary plasticity, Neotropical-plains stream, Pampean region

Resumen: Ecología alimentaria del siluriforme Pimelodella laticeps Eigenmann 1917, en un arroyo pampeano de la Argentina Pimelodella laticeps Eigenmann 1917 es el siluriforme más abundante en el arroyo El Pescado, situado en la zona deprimida en la región pampeana (Buenos Aires, Argentina). Para caracterizar sus hábitos alimentarios se analizó el contenido del tubo digestivo de peces capturados durante muestreos estacionales (desde mayo 1991 hasta agosto 1993). Se calculó el índice de importancia relativa (IRI) para evaluar la contribución de los diferentes componentes de la dieta. Pimelodella laticeps prefirió alimentarse en sectores con macrófitas acuáticas, depredando principalmente sobre organismos de las comunidades bentónicas y perifíticas. Su alimento principal fueron los copépodos ciclopoideos, que por lo general tienen hábitats litorales o bentónicos, y solo ocasionalmente habitan el plancton. Los organismos planctónicos disponibles en el ambiente se analizaron mediante la prueba de Olmstead-Tukey, test que indicó como ítems dominantes a los copépodos, ostrácodos y larvas de quironómidos. Los cladóceros Chydoridae, los copépodos Harpacticoida, las larvas de efemerópteros y los anfípodos también fueron dominantes, pero con una frecuencia menor. La dieta de P. laticeps se comparó con los organismos planctónicos disponibles y se analizó mediante un análisis multivariado no paramétrico (ANOSIM de una vía basado en permutaciones) a fin de comprender las estrategias de alimentación. Si bien algunos de los ítems discriminantes de las diferencias encontradas fueron del plancton, y estos se identificaron con valores altos en el ambiente, P. laticeps no consumió organismos planctónicos de manera significativa.

Palabras clave: Hábitos alimentarios, bagre gris, plasticidad en la dieta, arroyo de llanura neotropical, región pampeana

\section{INTRODUCTION}

Pimelodella laticeps Eigenmann, 1917 (Siluriformes, Heptapteridae) (known as the gray catfish) is a Neotropical species distributed in lentic and lotic environments in Bolivia, Paraguay, southern Brazil, and Argentina (Ringuelet et $a l ., 1967)$. The southern end of the species distribution is the Sierra de la Ventana hills and the Chasicó Stream (south of the Buenos Aires province; Menni et al., 1988). It was also found in brackish water of the Samborombón Bay (García \& Almirón, 1991) and in the shallow lake El Estado (Grosman \& Sanzano, 2003).

Low temperature was identified as the most influential condition determining the southern boundary of Neotropical-fish distribution 


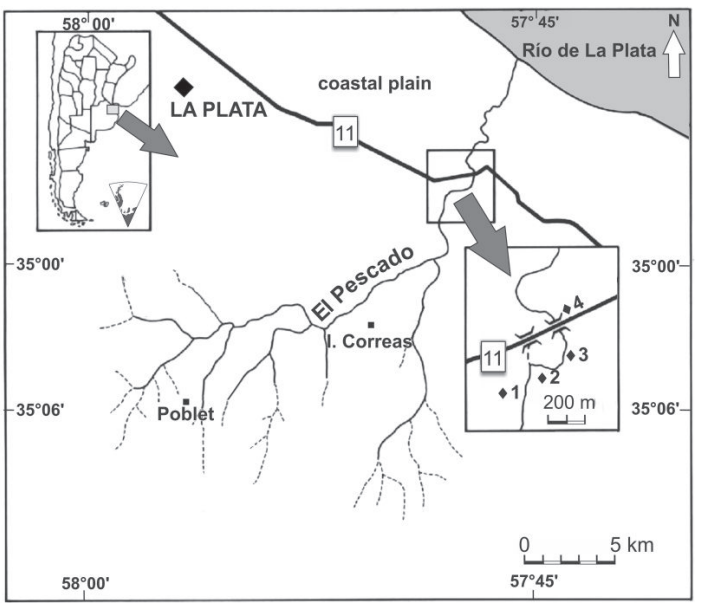

Fig. 1. Sampling sites in El Pescado Stream.

in Argentine freshwater ecosystems, although certain other species have shown better acclimation to colder conditions (Colautti et al., 2015). Baigún et al.(2002) attributed the absence of $P$. laticeps in northern Patagonia to its low tolerance to cold temperatures.

Pimelodella laticeps is the most abundant siluriform fish in the El Pescado Stream, where the species inhabits throughout the year. Almirón et al. (2000) and López van Oosterom et al. (2013) remarked that $P$. laticeps is a permanent species in the El Pescado Stream because of the fish ecologic plasticity facing the marked instability of habitat. Colautti et al. (2009) noted that the species is also permanent in the La Choza Stream; whereas Paracampo (2012) recorded the catfish as a semipermanent species in El Pescado Stream.

El Pescado Stream is located in the ecotone between the subtropical and the Patagonian fish fauna regions. It is inhabited by 55 fish species, with $P$. laticeps being the most abundant from the remote sites down to the mouth of the stream (Almirón et al. 2000). Macluf et al. (1998) mentioned that the zooplankton found in this stream offered high-quality food for fish, and that $P$. $l a$ ticeps prefers to feed on the microcrustacean assemblage.

Several $P$. laticeps-population estimations have been made in pampean shallow lakes (Freyre et al., 1966,1967; Alaimo \& Freyre, 1969). Some specific aspects of the P. laticeps biology are quite well known-such as the morphometry (Freyre \& Mollo, 1987), the structure of the pectoral spines (Bisbal \& Gómez, 1986), and the concentration of dissolved oxygen lethal to the fish (Gómez, 1993). In relation to water quality, an investigation on the fish assemblage from the River Suquía concluded that the genus Pimelodella lives only at sites with good water quality (Hued \& Bistoni, 2007). After the first studies on diet of $P$. laticeps in pampean environments (Destefanis \& Freyre, 1972; Escalante, 1984), the interest in characterizing the eating habits of the gray catfish increased recently (Grosman et al., 2002; Freyre et al., 2003; Diovisalvi et al., 2010; Fernández et al., 2012; López van Oosterom et al., 2013).

The objectives of this study were: to analyze the seasonal variations of the feeding habits of P. laticeps in the El Pescado Stream; to compare those results with the available food; and to describe the species' environmental circumstances when the stream was not yet affected by human activity, in order to provide a tool for assessing the current condition of the environment, both there and elsewhere. To fulfill these objectives, we took into account the seasonal analyses of the plankton in the El Pescado Stream performed in the same decade by Macluf et al. (1998).

\section{MATERIALS AND METHODS}

\section{Study area}

El Pescado Stream is located in a depressed area known as Pampean region, within the lower Río de la Plata basin in the Buenos Aires province, Argentina $\left(35^{\circ} 55^{\prime} \mathrm{S}, 57^{\circ} 45^{\prime} \mathrm{W}\right.$; Frenguelli, 1950) (Fig. 1). This watershed is the northernmost of the four basins in the large plain covering most of the eastern central latitude of Argentina (from $34^{\circ} 00^{\prime}$ to $38^{\circ} 30^{\prime} \mathrm{S}$ ). This stream flows in an area at the southern border of the Subtropical Zoogeographic Dominion (Ringuelet, 1961; Almirón et al., 2000), and after $36 \mathrm{~km}$ is channeled into the coastal plain, from where the channel becomes directed to the Río de la Plata estuary. El Pescado has a basin of $400 \mathrm{~km}^{2}$, a slope of $0.6 \mathrm{~m} / \mathrm{km}$ and develops as a plain stream with a variable flooding frequency; its input coming from groundwater and from numerous tributaries. The surrounding basin is an agricultural area with crops of soybean, corn, wheat, and alfalfa and some livestock.

Four sampling sites with different topographies (Fig. 1) were selected as cited in Almirón et al. (2000). The samples for that study and the present one were all collected as indicated here, in 1991 through 1993. Those authors subsequently published the data on the relative abundance of the fish assemblage; the results we present here, from the same original samplings, constitute a retrospective evaluation of the ecologic situation 
at that time from the standpoint of the feeding habits of $P$. laticeps, which was only captured at sites 1, 2 and 3, where Almirón et al. (2000) described the presence of macrophytes during the same sampling period. Ceratophyllum demersum, Potamogeton striatus, and Schoenoplectus californicus were present during the entire sampling period. Submerged and swamp macrophytes -such as Alternanthera philoxeroides, Hydrocotyle ranunculoides, Ludwigia sp., Myriophyllum aquaticum, M. quitense, and Polygonum sp.- were present during the early spring through the summer, whereas the floating vegetation -such as Azolla filiculoides, Lemna sp., Limnobium laevigatum, Spirodella intermedia, and Ricciocarpus natansdeveloped in the later spring.

Thisevaluation was done within thementioned environmental context, but with statistical methods for comparative analysis presently available.

\section{Samplings and data analysis}

Samplings were performed seasonally from May 1991 through August 1993, except in May 1992 and May 1993 because of floodings. The fish were caught with a seine net $(15 \mathrm{~m}$ long x $1 \mathrm{~m}$ high, with a cod end $1.5 \mathrm{~m}$ long, mesh 5-10 mm). The catch effort had the same intensity at each site. The specimens were fixed in situ with $10 \%$ formaldehyde and measured (standard length, SL), weighed, and sexed in the laboratory. After dissection of the digestive tracts, the contents were removed and placed in 5\% formaldehyde. The minimum sample size was calculated under the assumption of a Poisson distribution as follows: $\mathrm{n}=(200 \mathrm{cv} / \mathrm{r})^{2}=(200 / \mathrm{r})^{2} \mathrm{x}^{-1}$, where $\mathrm{n}$ is a sample size required for a Poisson variable; $r$ is a desired relative error (as a percent); $\mathrm{cv}$ is the coefficient of variation $=1 / x($ Krebs, 1989). The dietary contents were fully analyzed with respect to quality and quantity to the lowest possible categories by observation in counting chambers under the stereomicroscope and optical microscope. The number, weight, and volume of the dietary items were recorded. The volume of the microcrustaceans was obtained by liquid displacement (Escalante, 1982) and the algal volume determined as biovolume (Reynolds, 1984; Lewis, 1976; Wetzel \& Likens, 1991; García de Emiliani, 1993). To evaluate the significance of the different dietary components, the index of relative importance (IRI; Pinkas et al., 1971) was used: IRI $=\mathrm{FO}(\mathrm{N}+\mathrm{V})$, which parameter is a function of the percent frequency of occurrence (FO) and the numerical $(\mathrm{N})$ and volumetric $(\mathrm{V})$ percentages of the various items consumed in the diet.
The relative abundance of each item was obtained and the feeding habits compared between the different seasons through analysis of the gut-content-abundance values by means of a nonparametric multivariate analysis (a permutation-based one-way ANOSIM; Clarke \& Warwick, 2001). In this way, a similarity-percentage analysis (SIMPER) was used to identify the so-called discriminating items that most highly contributed to accounting for the observed similarity (or dissimilarity) between samples. This method uses the Bray-Curtis measure of similarity by comparing, in succession, each sample in one group with every sample in another set. Finally, in order to understand the feeding strategies of P. laticeps, the fish's diet was compared with the plankton availability recorded by Macluf et al. (1998). This plankton community was analyzed by means of the Olmstead-Tukey method (Sokal \& Rolf, 1979), a nonparametric association test that allows to determinate dominant, frequent, rare, and common items. This information was also used to compare by multivariate analysis (ANOSIM) between the plankton available in the environment and the consumed items of this assemblage. SIMPER was also used to identify the discriminating items accounting for this similarity (or dissimilarity). Before both analyses, the rare species were discarded from the general matrix, and the data were then transformed to $\log (\mathrm{x}+1)$ to reduce the contribution of the most highly abundant species. For these comparisons, fish and plankton samples were obtained at the same time (as explained in reference to the study area above).

\section{RESULTS}

\section{Sampling results}

The specimens of $P$. laticeps were captured only at sampling sites 1,2 and 3 with the presence of $S$. californicus and thus with a welldeveloped epiphytic community. The capture abundances were 228 (Site 1), 349 (Site 2), and 24 (Site 3) individuals. One hundred thirty fish were examined for diet analyses; including $15 \mathrm{ju}-$ veniles (SL: $29.3-41.5 \mathrm{~mm}$; weight: $0.3-1 \mathrm{~g}$ ), 62 females (SL: 39.4-78.2,weight: 0.9-8.2 g), and 53 males (SL 35.3-62 mm; weight: 0.6-3.6 g). The minimum sampling was 73 stomachs.

\section{Fish diet}

ThedietofP.laticeps resultedin 1,470 consumed prey from 52 taxa. Tables $1 \mathrm{a}$ and $1 \mathrm{~b}$ illustrate the seasonal variations in the composition of that diet and provide taxonomic details of the items therein. 
The year-round diet of $P$. laticeps contained mainly cyclopoid copepods, present in $18 \%$ of the examined stomachs; with Ectocyclops phaleratus, Macrocyclops albidus, and Tropocyclops prasinus -typical periphytic or benthic species- along with Acanthocyclops robustus -the only planktonic species- being recorded.

The benthic organisms were the second most highly consumed. The chironomid larvae appeared in $15 \%$ of the analyzed stomachs, while the mayfly nymphs (Ephemeroptera) were present in $10 \%$ and ostracods in $9 \%$, followed by cladocerans in $7 \%$. The Chydoridae cladocerans, which are common in the periphyton and sparsely represented in the plankton, were the most abundant in the diet. Moreover, the harpacticoid copepods were present in $6 \%$ of the stomachs along with the amphipods. The chrysophytes were found in 5\% of the stomachs in winter 1993, but they were absent in the planktonic samples. The insects and macrophyte fragments both remained at a $4 \%$ frequency. Cyanobacteria, chlorophytes, euglenophytes, pyrrophytes, charophytes, rotifers, nematodes, amphipods, acari, tardigrades, molluscs, and fish remains were present at a frequency of fewer than $2 \%$ of the analyzed stomachs. It is noteworthy that cyanobacteria, chlorophytes, euglenophytes, pyrrophytes, and rotifers were however present in the planktonic samples. Table 2 shows the percent frequency of occurrence, number and volume, and the index of relative importance (IRI) of the main groups found in the diet of $P$. laticeps.

The multivariate analysis showed that the diet composition changed during the different sampling dates (ANOSIM, $\mathrm{R}=0.45 \mathrm{p}<0.05$ ); and when the data were compared according to seasonality, significant differences between seasons were observed (ANOSIM, $\mathrm{R}=0.27 \mathrm{p}$ $<0.05$ ). Table 3 lists the percentages of dissimilarity between seasons (SIMPER). Data in this table indicate that cyclopoid copepods, chironomids, and ostracods were the responsible for the differences in the diet between seasons and that cyclopoid copepods were the most highly consumed item; this statement is especially true for autumn when this season was compared with the others and for summer when the latter was compared with spring and winter.

Among the 1,470 total preys consumed during the year, cyclopoid copepods (copepodites and adults) dominated the diet during autumn, whereas calanoid copepod nauplii were abundant in the plankton in the same season. The latter appear in $100 \%$ of the stomachs analyzed, rep- resenting $87 \%$ of the food consumed. The second most frequent food item was the ostracods and chironomid larvae, with those two taxa appearing at a somewhat lower proportion. Other prey had a lower representation in the diet (1\%). The algae were not consumed during this season, except for Surirella ovalis and Oedogonium sp.

During winter, benthic organisms were the principal components of the diet. The diatoms Aulacoseira distans, Melosira varians, Navicula sp., and Ulnaria ulna were the most frequent items, those being registered in $43 \%$ of the examined stomachs. The cyclopoid copepods $E$. phaleratus, M. albidus, and T. prasinus; the chydoridcladoceran Coronatella rectangula, chironomid larvae; and the ephemeropteran nymphs followed in frequency.

The highest number of total items consumed was recorded in spring $(\mathrm{N}=43)$. In this season the prey with the highest absolute frequency werethe chironomids and cyclopoid copepods (65.6\% each), followed by amphipods $(53.1 \%)$, chydoridcladocerans (46.84\%), and harpacticoid copepods (40.6\%) in the analyzed stomachs (Table 1b). Furthermore, a wide variety of algae including diatoms, chlorophytes, euglenophytes, pyrrophytes, and charophytes were also found (Table 1a).

In summer the fish also preferred feeding on cyclopoid copepods, chironomid larvae, and ostracods; with those respective taxa being found in $69 \%, 55 \%$, and $39 \%$ of the stomachs analyzed. Harpacticoid copepods, represented at a frequency of $22 \%$, were also often consumed (Table $1 \mathrm{~b}$ ).

\section{Food availability}

The plankton community in El Pescado Stream offered a wide range of available food comprising 103 phytoplanktonic species (cyanobacteria, chrysophytes, chlorophytes, euglenophytes, and pyrrophytes) and 152 zooplanktonic species (testate amoebae, ciliates, rotifers, copepods, and cladocerans) (Macluf et al. 1998).

In the Olmstead-Tukey diagrams (Figs. 2 and 3), the dominant dietary items were copepods, ostracods, and chironomids. Chydorids, harpacticoids, mayfly nymphs (Ephemeroptera), and amphipods were also highly prevalent, but somewhat less frequent. Among the occasional available food items were algae at high frequencies (chlorophytes and diatoms), with Daphnia sp., the remains of macrophytes and insects (dipteran adults and larvae), scales, and acari (not shown) being less frequent. 


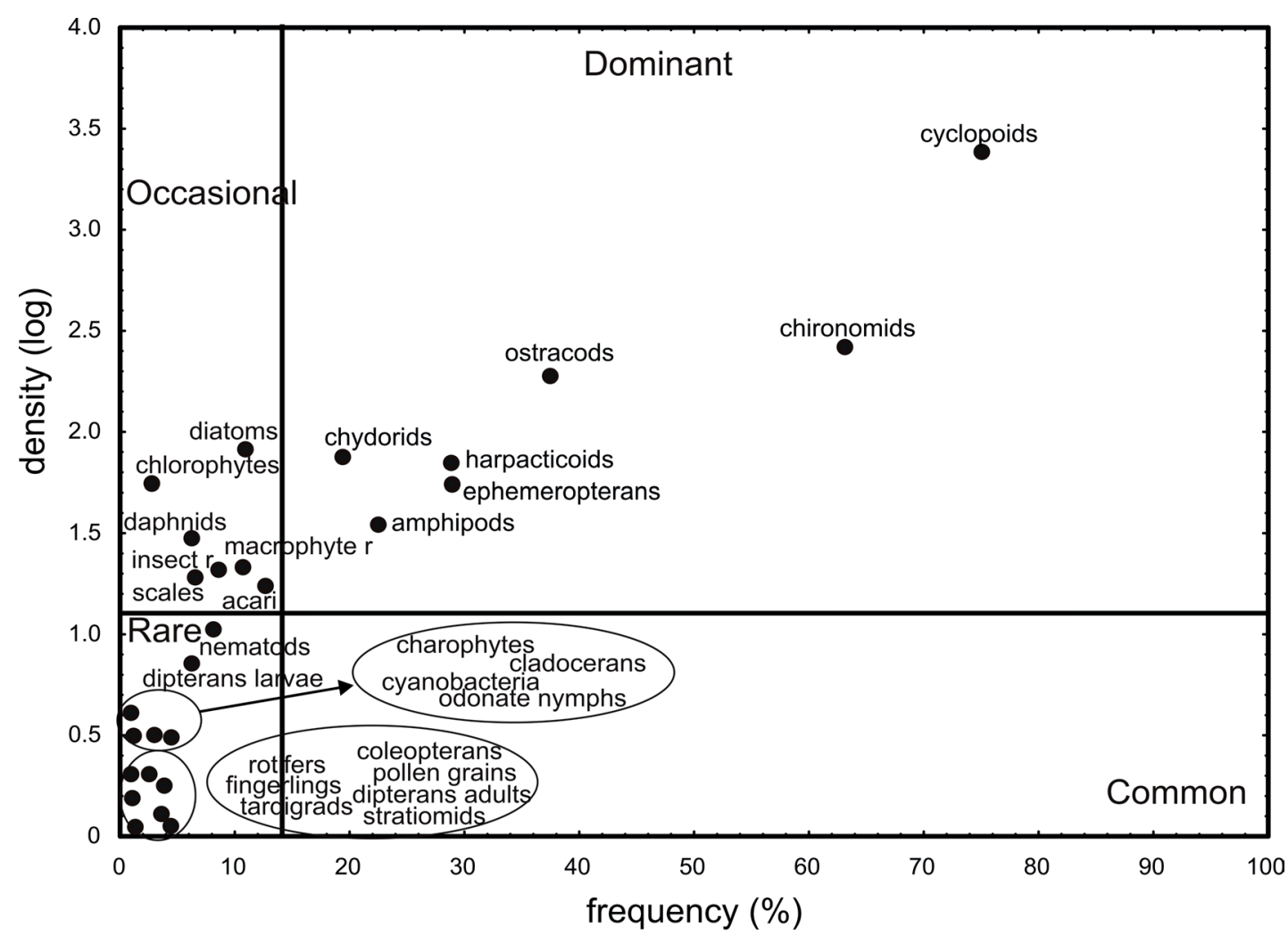

Fig. 2. Olmstead-Tukey diagram showing the distribution and abundance of the dietary items of Pimelodella laticeps expressed as taxonomic groups when recognizable (otherwise stated as remains or materials). The items in the occasional and rare sectors of the graph are indicated by abbreviations. In the figure, the logarithm of the item density is plotted on the ordinate as a function of the percent frequency on the abscissa. Those taxa found at both a low frequency and density are arbitrarily classified as rare; at a high frequency but low density as common; at a low frequency but high density as occasional; and at both a high frequency and density as dominant.

\section{Comparison between fish diet and food availability}

The relative abundances of phytoplankton and zooplankton found in the environment were different from those in the diet (ANOSIM, $\mathrm{R}=$ $0.87 \mathrm{p}<0.05$ and $\mathrm{R}=0.99 \mathrm{p}<0.05$, respectively). Pimelodella laticeps consumed almost no phytoplankton, while the discriminating items from this assemblage were identified as having high values in the environment (Table 4). The dissimilarity between the zooplankton taxa available and those consumed was also high, with a smaller number of items indicated as discriminating because of their high values in the environment but being almost absent in the diet (rotifers and nauplii larvae) and the cyclopoid copepods for having high values in the diet (Table 4).

\section{DISCUSSION}

In the present study, P. laticeps was captured only at sites with dense mats of Schoenoplectus californicus covering the shores throughout the year; which macrophytes likely provide refuge and food, even during floods. The relationships between fish and submerged plants in warmer climatic regimes still remains incompletely studied (Jeppesen et al., 2005); and according to some authors, fish communities associated with plants appear to be characterized by a high proportion of omnivorous species (Winemiller, 1990; Branco et al., 1997) that, for their part, have different effects on other trophic levels than those predicted by the trophic-cascade theory (Lazzaro, 1997; Pace et al., 1999).

Our analysis indicated that in El Pescado Stream P. laticeps mainly predated upon organisms from the periphytic and benthic communities. The main food was cyclopoid copepods, which taxon usually has littoral or benthic habitats and, to a lesser extent, is also a part of the plankton community (Reid, 1985). Among these 


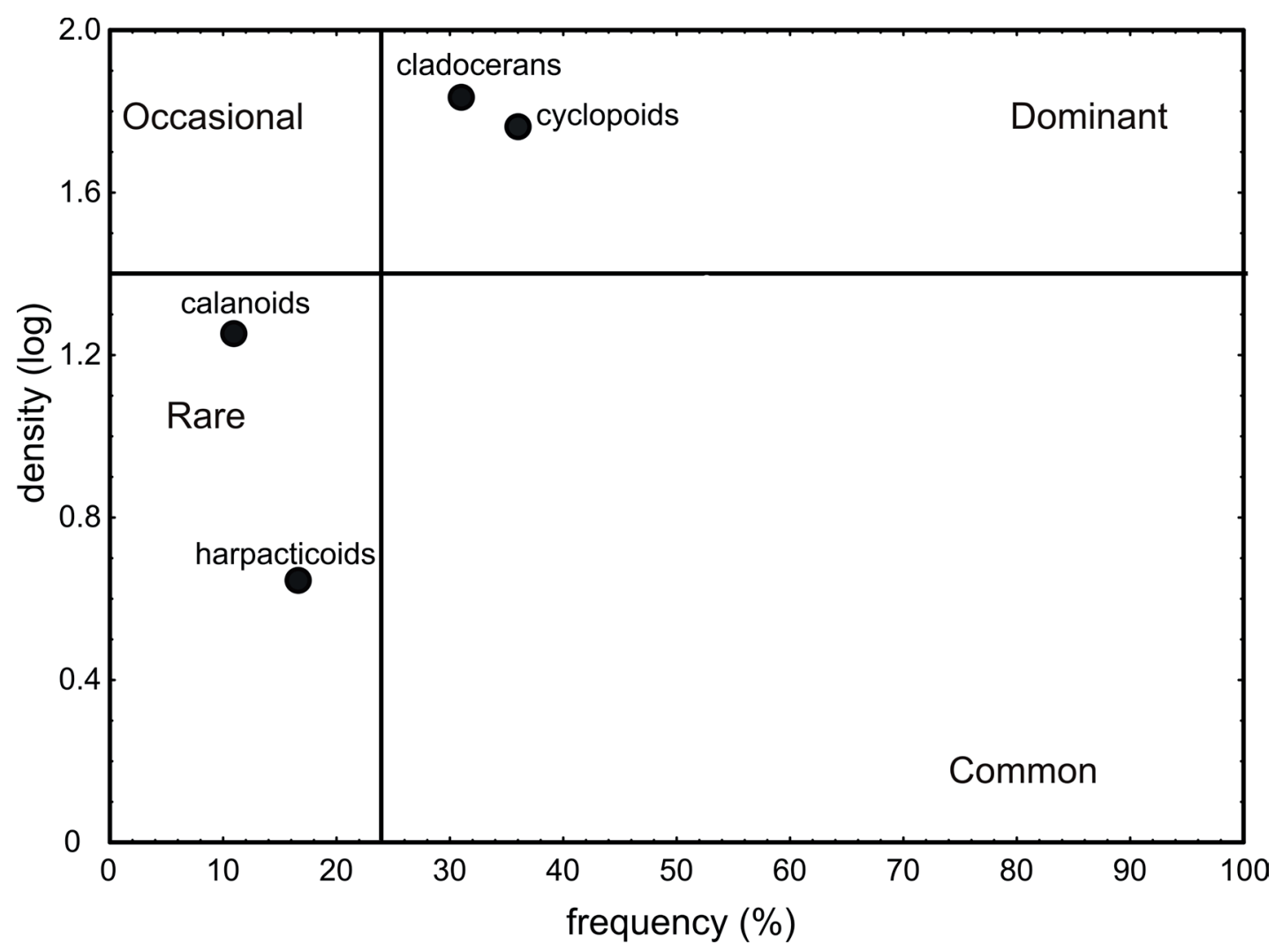

Fig. 3. Olmstead-Tukey diagram showing the offer of microcrustacean zooplankton in El Pescado Stream. For the axes and definition of sectors cf. legend of Fig. 2.

species, Acanthocyclops robustus lives mainly in the limnetic zones of large ponds and lakes (Dussart \& Fernando 1990); Ectocyclops phaleratus is an uncommon benthic species, inhabiting mainly the littoral zone and only occasionally the water column (Dussart, 1969; Reid, 1985); Macrocyclops albidus lives among macrophytes, reaching its maximum development during summer (Pennak 1966); and Tropocyclops prasinus is a common species within the periphytic and benthic communities (Dussart, 1969), in warm waters, tolerating brackish water, and rarely behaving as planktonic (Margalef, 1983). Chironomid larvae and mayfly nymphs, which taxa are common in lotic and lentic Neotropical environments where the food availability is ample (Marchese, 1984; Kaisin, 1989; López van Oosterom et al., 2013), were found in the diet of P. laticeps at high frequencies during spring.

Ostracods were another major item recorded in the diet. These crustaceans increased theirrelative abundance from spring to summer and then autumn, but decreased in winter. These diet variations were coincident with the seasonal fluctuations in ostracod abundance, and thus availability, in the environment; as had been observed in other temperate streams within the area (Sampóns, 1988).

The diet of the specimens of $P$. laticeps captured in El Pescado Stream was similar to that from La Choza Stream (López van Oosterom et al., 2013) as regards invertebrate larvae, probably in relation with the presence of macrophytes. In contrast, some differences arose when comparing main food items. Cyclopoid copepods and chironomid larvae constituted the main food of P. laticeps in El Pescado, while mayfly larvae and ostracods were found to serve as complementary food items, as had been pointed out in La Choza Stream by López van Oosterom et al. (2013). Cyclopoid copepods are widespread and play a major role in the trophic dynamics of freshwater ecosystems (Hopp et al., 1997). Grossman et al. (2002) mentioned the degree of relevance of planktonic microcrustaceans in feeding the fish of the shallow lake San Miguel del Monte, even in clearly benthic species such as the siluriforms $P$. laticeps and Corydoras paleatus (Jenyns, 1842). 
Table 1a. Absolute frequency (AF), relative frequency $(\mathrm{RF})$ and density $(\mathrm{N})$ of vegetable items in the diet composition of Pimelodella laticeps in each season.

\begin{tabular}{|c|c|c|c|c|c|c|c|c|c|c|c|c|}
\hline & \multicolumn{3}{|c|}{ AUTUMN } & \multicolumn{3}{|c|}{ WINTER } & \multicolumn{3}{|c|}{ SPRING } & \multicolumn{3}{|c|}{ SUMMER } \\
\hline & $\mathrm{AF}$ & $\mathrm{RF}$ & $\mathrm{N}$ & $\mathrm{AF}$ & $\mathrm{RF}$ & $\mathrm{N}$ & $\mathrm{AF}$ & $\mathrm{RF}$ & $\mathrm{N}$ & $\mathrm{AF}$ & $\mathrm{RF}$ & $\mathrm{N}$ \\
\hline \multicolumn{13}{|l|}{ CYANOPHYTA } \\
\hline Anabaenopsis sp. & & & & & & & 3.12 & 0.19 & 1 & & & \\
\hline Oscillatoria sp. & & & & 4.35 & 1.60 & 3 & & & & & & \\
\hline \multicolumn{13}{|l|}{ CHRYSOPHYTA } \\
\hline Actinoptychus sp. & & & & & & & & & & 1.96 & 0.07 & 1 \\
\hline A. undulatus & & & & & & & 3.12 & 0.19 & 1 & & & \\
\hline Amphora sp & & & & & & & & & & 1.96 & 0.07 & 1 \\
\hline Denticula sp. & & & & & & & 3.12 & 0.19 & 1 & & & \\
\hline Eunotia sp. & & & & 4.35 & 1.60 & 1 & & & & & & \\
\hline Gomphonema sp. & & & & & & & 3.12 & 0.19 & 1 & & & \\
\hline G. herculeana & & & & & & & 3.12 & 0.19 & 2 & & & \\
\hline Aulacoseira distans & & & & 8.69 & 11.23 & 21 & & & & & & \\
\hline Melosira varians & & & & 8.69 & 2.67 & 5 & 3.12 & 0.19 & 1 & & & \\
\hline Navicula sp. & & & & 4.35 & 0.53 & 1 & 3.12 & 0.19 & 1 & & & \\
\hline Surirella ovalis & 3.84 & 0.05 & 1 & & & & 3.12 & 0.19 & 1 & 1.96 & 0.07 & 1 \\
\hline Ulnaria ulna & & & & 8.69 & 24.63 & 45 & 6.25 & 0.39 & 2 & & & \\
\hline \multicolumn{13}{|l|}{ CHLOROPHYTA } \\
\hline Closterium sp. & & & & & & & 6.25 & 0.78 & 4 & & & \\
\hline Oedogonium sp. & 3.84 & 0.05 & 1 & & & & & & & 1.96 & 0.07 & 1 \\
\hline Pediastrum boryanum & & & & & & & 3.12 & 0.39 & 2 & & & \\
\hline P. duplex & & & & & & & 3.12 & 0.39 & 2 & & & \\
\hline $\begin{array}{l}\text { Scenedesmus quadri- } \\
\text { cauda }\end{array}$ & & & & & & & 6.25 & 0.39 & 2 & & & \\
\hline S. spinosus & & & & & & & 3.12 & 0.39 & 2 & & & \\
\hline Spirogyra sp. & & & & & & & 3.12 & 1.4 & 10 & & & \\
\hline \multicolumn{13}{|l|}{ EUGLENOPHYTA } \\
\hline Lepocinclis sp. & & & & & & & 6.25 & 0.78 & 4 & & & \\
\hline Phacus sp. & & & & & & & 3.12 & 0.19 & 1 & & & \\
\hline P. longicauda & & & & & & & 3.12 & 0.19 & 1 & & & \\
\hline CHAROPHYTA & & & & & & & 3.12 & 0.78 & 4 & & & \\
\hline \multicolumn{13}{|l|}{ PYRROPHYTA } \\
\hline Peridinium sp. & & & & & & & 3.12 & 0.19 & 1 & & & \\
\hline \multicolumn{13}{|l|}{ MACROPHYTES } \\
\hline remains & 3.84 & 0.05 & 1 & 17.40 & 5.35 & 10 & 15.60 & 4.27 & 22 & 11.80 & 1.19 & 18 \\
\hline pollen grains & & & & 4.35 & 0.53 & 1 & 3.12 & 0.58 & 3 & & & \\
\hline
\end{tabular}

Planktonic pyrrophytes and diatoms were rarely predated by $P$. laticeps. The low intake of planktonic items during summer could be attributable to the low water levels that make the boundaries between communities imprecise (Escalante, 1982, 1983; Menni, 2004). Nevertheless, several algal groups appearing in winter and spring were not present in the diet.

A comparison between available and consumed food indicated a high preference of P. laticeps for cyclopoid copepods, which species are eurytopic and commonly occur in the periphyton or benthos. The periphytic cyclopoids found in the diet were also present in the planktonic samples obtained at the macrophyte-development sites. Acanthocyclops robustus was recorded in the digestive tract but not in the plankton samples during the studied period.

Although a marked preference for copepods and a lower opting for cladocerans were observed, $P$. laticeps showed a notable degree of food flexibility as the fish's diet changed according to food availability and in response to environment alterations. The choice of food became adapted not only to availability in the environment throughout seasons, as had been found in 
Table 1b. Absolute frequency (AF), relative frequency (RF) and density $(\mathrm{N})$ of animal items in the diet composition of Pimelodella laticeps in each season.

\begin{tabular}{|c|c|c|c|c|c|c|c|c|c|c|c|c|}
\hline & \multicolumn{3}{|c|}{ AUTUMN } & \multicolumn{3}{|c|}{ WINTER } & \multicolumn{3}{|c|}{ SPRING } & \multicolumn{3}{|c|}{ SUMMER } \\
\hline & $\mathrm{AF}$ & $\mathrm{RF}$ & $\mathrm{N}$ & $\mathrm{AF}$ & $\mathrm{RF}$ & $\mathrm{N}$ & $\mathrm{AF}$ & $\mathrm{RF}$ & $\mathrm{N}$ & $\mathrm{AF}$ & $\mathrm{RF}$ & $\mathrm{N}$ \\
\hline \multicolumn{13}{|l|}{ ROTIFERA } \\
\hline Filinia longiseta & & & & & & & 3.12 & 0.78 & 4 & 0.98 & 0.65 & 1 \\
\hline Keratella americana & & & & & & & 3.12 & 0.19 & 1 & 0.98 & 0.65 & 1 \\
\hline unidentified remains & 3.84 & 0.05 & 1 & & & & & & & & & \\
\hline \multicolumn{13}{|l|}{ COPEPODA } \\
\hline $\begin{array}{l}\text { Cyclopoida (unidenti- } \\
\text { fied) }\end{array}$ & 100 & 86.7 & 1,610 & 26.1 & 11.8 & 22 & 62.5 & 13.6 & 70 & 58.9 & 64.5 & 98 \\
\hline $\begin{array}{l}\text { Acanthocyclops robus- } \\
\text { tus }\end{array}$ & 3.84 & 1.67 & 31 & & & & & & & 1.96 & 0.73 & 11 \\
\hline Ectocyclops phaleratus & & & & & & & 3.12 & 0.78 & 4 & & & \\
\hline Macrocyclops albidus & & & & & & & & & & 5.88 & 10.3 & 156 \\
\hline Tropocyclops prasinus & & & & & & & & & & 1.96 & 0.99 & 15 \\
\hline Harpacticoida & 19.3 & 0.38 & 7 & 8.69 & 1.6 & 3 & 40.6 & 6.4 & 33 & 21.6 & 1.92 & 29 \\
\hline \multicolumn{13}{|l|}{ CLADOCERA } \\
\hline Cladocera fragments & & & & 13.0 & 3.74 & 7 & 3.12 & 0.39 & 2 & 3.92 & 0.13 & 2 \\
\hline $\begin{array}{l}\text { Chydoridae (uniden- } \\
\text { tified) }\end{array}$ & 3.84 & 0.32 & 6 & 13.0 & 7.49 & 14 & 40.6 & 11.8 & 61 & 7.84 & 0.26 & 4 \\
\hline Allona pulchella & & & & & & & 3.12 & 0.78 & 4 & & & \\
\hline A. rectangula & & & & & & & 3.12 & 0.78 & 4 & & & \\
\hline $\begin{array}{l}\text { Daphnidae (unidenti- } \\
\text { fied) }\end{array}$ & & & & & & & & & & 9.8 & 1.06 & 16 \\
\hline Daphnia sp. & & & & 4.35 & 1.6 & 3 & & & & 1.96 & 0.07 & 1 \\
\hline OSTRACODA & 57.7 & 6.19 & 115 & & & & 31.25 & 4.27 & 22 & 39.2 & 6.68 & 101 \\
\hline \multicolumn{13}{|l|}{ AMPHIPODA } \\
\hline Hyalella curvispina & 7.64 & 0.1 & 2 & 17.4 & 3.74 & 7 & 53.1 & 6.21 & 62 & 7.84 & 0.4 & 6 \\
\hline ACARINA & 15.4 & 0.21 & 4 & & & & 12.5 & 1.36 & 7 & 13.7 & 0.46 & 7 \\
\hline TARDIGRADA & & & & 4.35 & 0.53 & 1 & & & & 1.96 & 0.07 & 1 \\
\hline \multicolumn{13}{|l|}{ INSECTA } \\
\hline $\begin{array}{l}\text { Diptera (unidentified } \\
\text { larvae) }\end{array}$ & 3.84 & 0.05 & 1 & 8.69 & 1.07 & 2 & 3.12 & 0.19 & 1 & 7.84 & 0.4 & 6 \\
\hline Chironomidae (larvae) & 77 & 2.96 & 55 & 26.1 & 11.2 & 21 & 65.6 & 26.8 & 138 & 54.9 & 5.49 & 83 \\
\hline Stratyiomidae (larvae) & 3.84 & 0.05 & 1 & & & & & & & & & \\
\hline Coleoptera & & & & 4.35 & 0.53 & 1 & 9.37 & 0.58 & 3 & & & \\
\hline Odonata (fragments) & 3.84 & 0.05 & 1 & 4.35 & 0.53 & 1 & 6.25 & 0.38 & 2 & & & \\
\hline Zygoptera (nymphs) & 3.84 & 0.05 & 1 & & & & & & & 1.96 & 0.13 & 2 \\
\hline $\begin{array}{l}\text { Ephemeroptera (uni- } \\
\text { dentified) }\end{array}$ & 38.5 & 0.59 & 11 & 26.1 & 6.42 & 12 & 37.5 & 3.69 & 19 & 31.4 & 1.45 & 22 \\
\hline Hexagenia sp. & & & & & & & 9.37 & 0.57 & 3 & & & \\
\hline Insect fragments & 7.69 & 0.1 & 2 & 13.0 & 1.6 & 3 & 18.8 & 6.4 & 33 & 13.7 & 1.12 & 17 \\
\hline \multicolumn{13}{|l|}{ MOLLUSCA } \\
\hline Heleobia sp. & & & & 4.35 & 1.6 & 1 & & & & & & \\
\hline $\begin{array}{l}\text { PISCES } \\
\text { Cnesterodon decemma- } \\
\text { culatus }\end{array}$ & & & & & & & 3.12 & 0.19 & 1 & 1.69 & 0.07 & 1 \\
\hline scales & 3.84 & 0.16 & 3 & 8.69 & 1.07 & 2 & & & & 17.7 & 1.72 & 26 \\
\hline NEMATODA & 11.5 & 0.21 & 4 & & & & 6.25 & 0.38 & 2 & 9.8 & 0.46 & 7 \\
\hline
\end{tabular}


Tabla 2: Percent frequency of occurrence (FO), number $(\mathrm{N})$ and volume $(\mathrm{V})$, and the index of relative importance IRI $=$ FO $(\mathrm{N}+\mathrm{V})$ of the main groups found in the diet of Pimelodella laticeps.

\begin{tabular}{lrrrr}
\hline & FO & N & V & \multicolumn{1}{c}{ IRI } \\
\hline Copepods & 30.83 & 77.61 & 14.50 & $2,839.75$ \\
Chironomid larvae & 19.69 & 7.63 & 53.43 & $1,202.27$ \\
Ephemeropterans & 12.66 & 1.75 & 22.80 & 310.80 \\
Ostracods & 11.92 & 6.23 & 1.30 & 89.76 \\
Amphipods & 6.99 & 1.23 & 7.69 & 62.35 \\
Algae & 10.10 & 3.15 & 0.05 & 32.32 \\
Cladocerans & 8.81 & 3.25 & 0.14 & 29.86 \\
\hline
\end{tabular}

Table 3: Percentages of dissimilarity in diet composition of Pimelodella laticeps among seasons, and items found as discriminants of those differences indicating in which season dominated in relative abundance.

\begin{tabular}{|c|c|c|c|c|}
\hline & Autumn & Winter & Spring & Summer \\
\hline Autumn & 0 & & & \\
\hline Winter & $\begin{array}{c}80.00 \\
\text { cyclopoids \& chironomids } \\
(>\text { in autumn })\end{array}$ & 0 & & \\
\hline Spring & $\begin{array}{c}71.82 \\
\text { cyclopoids \& ostracods (> } \\
\text { in autumn) } \\
\text { chironomids ( }>\text { in spring) }\end{array}$ & $\begin{array}{c}80.35 \\
\text { chironomids \& cyclopoids } \\
(>\text { in spring) }\end{array}$ & 0 & \\
\hline Summer & $\begin{array}{c}47.67 \\
\text { cyclopoids \& chironomids } \\
(>\text { in autumn) } \\
\text { ostracods ( }>\text { in summer) }\end{array}$ & $\begin{array}{c}81.16 \\
\text { cyclopoids \& ostracods }(> \\
\text { in summer) }\end{array}$ & $\begin{array}{c}76.14 \\
\text { cyclopoids \& ostracods (> } \\
\text { in summer) } \\
\text { chironomids ( }>\text { in spring) }\end{array}$ & 0 \\
\hline
\end{tabular}

Table 4. Percentages of similarity for phytoplankton and zooplankton as source of food available and consumed by Pimelodella laticeps, percentages of dissimilarity between availability and diet, and items found as discriminants of those differences for having high availability or for being highly consumed.

\begin{tabular}{lcc}
\hline & Phytoplankton & Zooplankton \\
\hline Similarity in the availability (\%) & 26 & 68.5 \\
Similarity in the diet (\%) & 71.6 & 58 \\
Dissimilarity between availability and diet (\%) & 89.1 & 86.9 \\
Discriminant items for having high availability & Diatoms, chlorophytes and eugleno- & Rotifers and nauplii \\
& phytes & larvae \\
Discriminant items for being highly consumed & None & Cyclopoid copepods \\
\hline
\end{tabular}

other species (Townsend \& Winfield, 1985), but also to floodings occurring in El Pescado Stream during both sampled autumns (Almirón et al., 2000). These environmental disruptions were reflected later in the diet by the presence of plant remains that had been washed into the stream, a situation that was also observed in cichlid species (Jiménez-Badillo \& Nepita-Villanueva, 2000).

Food availability seems to be in some way a determining factor of food preference, since fish diet generally is a reflection of the abundance of food items found in the environment (JiménezBadillo \& Nepita-Villanueva, 2000).

Aquatic vegetation provides a high diversity of habitats in which the organisms that are food for predator fish develop (Giorgi et al., 2005). Seasonal changes in a fish's diet are generally the result of food availability (Wootton, 1998; Zavala-Camin, 1996). Wolf et al. (1988) found that certain groups of insects exhibit a higher abundance during the months of highest precipitation, thus offering a wider range of prey. In contrast, periods of drought were characterized as intervals of scarcity or low supply of both food and habitat resources (Lowe-McConnell, 1987; Wootton, 1998). Resource diminution under such conditions is characterized by a decrease in the total available water surface, which shrinkage increases competitive interactions while decreasing the allochthonous food availability, mainly 
in the form of insects (Wolf et al., 1988; ZavalaCamin, 1996).

Destefanis \& Freyre (1972) considered that the feeding strategy of $P$. laticeps was mainly planktivorous and that the fish occasionally fed on benthic organisms without significant alimentary preferences. Their results, however, were referred to a small sampling from a shallow pampean lake. In contrast, other authors have placed this catfish species among the micro- and meso-animalivorousfish, among those commonly dwelling in waters with abundant vegetation (Ringuelet, 1975).

Unlike the findings with other members of the family Heptapteridae living in highland environments (Haro et al., 2001) or in rivers and streams with forest galleries (Araujo Lima et al., 1995), allochthonous material was not observed in the diet of $P$. laticeps.

Differing types of feeding behavior were recorded in other species of the genus Pimelodella. For example, unlike $P$. laticeps, $P$. Gracilis Valenciennes, 1835 preferred benthic, planktonic, and pleustonic organisms -such as insect larvae, copepods, and rotifers; but not filamentous algae- thus indicating that this species is related to those three communities (Oliveros 1980). Other species in the family -such as Pimelodus maculatus (Lacépède, 1803) (Bonetto et al., 1963; Nomura et al., 1972; Alonso, 1978), Pimelodella hasemani Eigenmann, 1917 and Rhamdia sebae (Valenciennes, 1840) (Saul, 1975), Pimelodella chagresi (Steindachner, 1877) and Rhamdia wagneri (Günther, 1868) (Angermeier \& Karr, 1984), and Rhamdia cf. hilarii and Rhamdella minuta (Lütken, 1875) (Uieda, 1983)- are considered omnivorous. In most of those species diet, aquatic invertebrates and especially insects (e. g., mayfly nymphs, chironomid larvae, trichopterans, and larval and adult coleopterans) dominate.

The diet of Pimelodella australis Eigenmann, 1917 was studied by González-Bergonzoni (2011) and Masdeu (2011), who classified it two possible functional groups: (1) omnivorous-benthivorous with inclusion of zooplankton, and (2) omnivorous-benthivorous with a herbivorous tendency. Teixeira et al. (2009) also placed P. australis in the omnivore-benthic-planktivorous trophic group residing in temperate and subtropical lakes.

In view of all the above considerations, $P$. laticeps appears to be a species with a high degree of dietary plasticity; as organism's trophic position depends of the available energy sources and the distribution of resources models its ecologic niche (Odum \& Barrett, 2005). The diet is a key determinant that provides information on the interrelationships between foraging behavior, distribution, and physiologic needs along with the abundance of food. Generalist species feed upon a broad spectrum of food in terms of the number of species and their microhabitats, with no marked preference for a particular food source; whereas specialists maintain a diet restricted to a relatively small number of food items (Gerking, 1994). The occurrence of generalist or specialist species in a particular habitat appears to be influenced mainly by the dynamics of their food resources. A predominance of generalist species inhabiting rivers has been recognized because of the ephemeral character of that habitat (Lowe McConnell, 1987; Araujo Lima et al., 1995). A large number of species have the ability to change their eating habits in response to seasonal and/or spatial variations in the availability of food. This flexibility means that those species have the ability to take advantage of a given food source at different times or places (Gerking, 1994; Chemes et al., 2010). In conclusion, because at the time of this study this area had been proposed as a provincial natural reserve, when that environment was in a relatively pristine state, the results obtained by this investigation can be regarded as a critically relevant tool for pursuing the objective of studying the El Pescado Stream more extensively now, when its condition is no longer pristine. The information obtained on the P. laticeps diet and the species' response to food availability and habitat distribution could be used in future studies evaluating the change in environmental status that characterizes this and other related lotic environments -some of which may still have remained pristine- within the pampean region of Argentina.

\section{ACKNOWLEDGEMENTS}

Authors especially thank Dr. R. Menni for the critical reading of the manuscript. We thank Dra. M. C. Claps for the identification of crustaceans, Dra. N. Turfor the identification of macrophytes, Dra. A. Almirón for her assistance in field sampling, and Dr. H. Benítez for his assistance in graphic design. Dr. Donald F. Haggerty, a retired academic career investigator, edited the final version of the manuscript. The authors wish to thank two anonymous reviewers for their valuable comments on the manuscript. 


\section{REFERENCES}

Alaimo, S. \& L. Freyre. 1969. Resultados sobre estimación de numerosidad de peces en la laguna de Chascomús (Provincia de Buenos Aires). Physis 29(78): 197-212.

Almirón, A.E., M.L. García, R.C. Menni, L.C. Protogino, \& L.C. Solari. 2000. Fish ecology of a seasonal lowland stream in temperate South America. Marine and Freshwater Research 51: 265-274.

Alonso, C. 1978. Estudio del contenido gástrico de Pimelodus clarias maculatus(Lacépède, 1803) (Pisces, Pimelodidae). Iheringia, Série Zoologia 51: 47-61.

Angermeier, P.L. \& J.R. Karr. 1984. Fish communities along environmental gradients in a system of tropical streams. Pp. 39-57in: Zaret, T.M. (ed.). Evolutionary ecology of Neotropical freshwater fishes. The Hague: Junk. 173 pp.

Araujo Lima, C.A.R.M., A.A. Agostinho \& N.N. Fabre. 1995. Trophic aspects of fishes communities in Brazilian rivers and reservoirs. Pp. 105-136 in: Tundisi, J.G., C.E.M. Bicudo \& T. Matsumara Tundisi (eds.). Limnology in Brazil. Rio de Janeiro: Brazilian Academy of Sciences \& Brazilian Limnological Society.

Baigún C., G. López, A. Dománico, R. Ferriz, S. Sverlij \& R.D. Schenke. 2002. Presencia de Corydoras paleatus (Jenyns, 1842), una nueva especie brasílica en el norte de la Patagonia (río Limay) y consideraciones ecológicas relacionadas con su distribución. Ecología Austral 12: 41-48.

Bisbal, G.A. \& S.E. Gómez. 1986. Morfología comparada de la espina pectoral de algunos siluriformes bonaerenses (Argentina). Physis B 44(107): 81-93.

Bonetto, A.A., C. Pignalberi \& E. Cordiviola. 1963. Ecología alimentaria del "amarillo" y "moncholo" Pimelodus clarias (Bloch) y Pimelodus albicans (Valenciennes) (Pisces, Pimelodidae). Physis 24: 87-94.

Branco, C.W.C., T. Aguiaro, F.A. Esteves \& E.P. Caramaschi. 1997. Food source of the teleost Eucinostomus argenteus intwo coastal lagoons of Brazil. Studies on Neotropical Fauna and Environment 32: 33-40.

Chemes, S.B., A.R. Giraudo \& G. Gil. 2010. Dieta de Lontra longicaudis (Carnivora, Mustelidae) en el Parque Nacional El Rey (Salta, Argentina) y su comparación con otras poblaciones de la cuenca del Paraná. Mastozoología Neotropical 17(1): 19-29.

Clarke, K. R. \& R. M. Warwick. 2001. A further biodiversity index applicable to species lists: variation in taxonomic distinctness. Marine Ecology Progress Series 216: 265-278.

Colautti, D.C., M.E. Maroñas, E.D. Sendra, L.C. Protogino, F. Brancolini \& D. Campanella. 2009. Ictiofauna del arroyo La Choza, cuenca del Río de la Reconquista (Buenos Aires, Argentina). Biología Acuática 26:55-62.

Colautti, D., C. Baigún, F. Llompart, T. Maiztegui, J. Garcia de Souza, P. Solimano, L. Balboni \& G. Berasain. 2015. Fish assemblage of a Pampean shallow lake, a story of instability. Hydrobiologia 752: 175-186.

Destefanis, S. \& L. Freyre. 1972. Relaciones tróficas de los peces de la laguna de Chascomús con un intento de referenciación ecológica y tratamiento bioestadístico del espectro trófico. Acta Zoologica Lilloana 29: 17-33.

Diovisalvi, N., G. Berasain, F. Unrein, D. Colautti, P. Fermani, M.E. Llames, A.M. Torremorell, L. Lagomarsino, G. Pérez, R. Escaray, J. Bustingorry, M. Ferraro \& H.E. Zagarese. 2010. Chascomús: estructura y funcionamiento de una laguna pampeana turbia. Ecología Austral 20: 115-127.

Dussart, B. 1969. Les copépodes des eaux continentales d'Europeoccidentale: Cyclopoïdes et biologie(Vol. 2). París: Boubée. 292 pp.

Dussart, B.H. \& C.H. Fernando. 1990. A review of the taxonomy of five Ontario genera of freshwater cyclopoidCopepoda (Crustacea). Canadian Journal of Zoology 68(12): 2594-2604.

Escalante, A.E. 1982. Contribución al conocimiento de las relaciones tróficas de peces de agua dulce del área platense. I. Astyanax eigenmaniorum (Osteichthyes, Tetragonopteridae). Limnobios 2(5): 311-322.

Escalante, A.E. 1983. Contribución al conocimiento de las relaciones tróficas de peces de agua dulce del área platense. III. Otras especies. Limnobios 2(7): 453-483.

Escalante, A.H. 1984. Contribución al conocimiento de las relaciones tróficas de peces de agua dulce del área platense. IV. Dos especies de Cichlidae y miscelánea. Limnobios 2(8): 562-578.

Fernández E.M., R.A. Ferriz, C.A. Bentos \& G.R. López. 2012. Dieta y ecomorfología de la ictiofauna del arroyo Manantiales, provincia de Buenos Aires, Argentina. Revista del Museo Argentino de Ciencias Naturales n. s. 14(1): 1-13.

Frenguelli, J. 1950. Rasgos generales de la morfología y la geología de la Provincia de Buenos Aires. La Plata: Ministerio de Obras Públicas de la Provincia de Buenos Aires. 72 pp.

Freyre, L., N. Iriart, R.A. Ringuelet, C. Togo \& J. Zetti. 1967. Primeros resultados sobre estimación de poblaciones de peces de "lagunas" pampásicas. Physis 26(73): 421-433.

Freyre, L., N. Iriart, C. Togo \& J. Zetti. 1966. Estudios ictiológicos. (Ictiometría básica. Obtención de datos numéricos y merísticos. Cálculo de numerosidad de poblaciones de peces. Edad y crecimiento del pejerrey. Distribución ecológica de la ictiofauna de Chascomús). In: Trabajos Técnicos, $1^{\text {ra }}$ etapa (1965). La Plata:Convenio Estudio Riqueza Ictícola (mimeographed).

Freyre, L.R. \& S.M. Mollo. 1987. Estudio biométrico para estimar el tamaño y peso de los peces a partir de las dimensiones de sus otolitos. Revista de la Asociación Ciencias Naturales del Litoral 18(2): 145-154.

Freyre L.R., M.E. Maroñas, S.M. Mollo, E.D. Sendra \& A.A. Dománico. 2003. Variaciones supra-anuales de la ictiofauna de lagunas bonaerenses. Biología 
Acuática 20: 63-67.

García, M.L. \& A.E. Almirón. 1991. Presencia de Pimelodella laticeps (Pisces, Pimelodidae) en un ambiente de salinidad variable. Neotropica 37(97): 66.

García de Emiliani, M.O. 1993. Seasonal succession of phytoplankton in a lake of the Paraná River floodplain, Argentina. Hydrobiologia, 264: 101-114.

Gerking, S.D. 1994. Chapter 7. Larval feeding.Pp. 139170 in: Gerking, S.D. (ed.). Feeding ecology of fish . San Diego (California): Academia Press. 416 pp.

Giorgi, A., C. Feijoo \& G. Tell. 2005. Primary producers in a Pampean stream: temporal variation and structuring role. Biodiversity and Conservation 14: 1699-1718.

Gómez, S. 1993. Concentración letal de oxígeno disuelto para Corydoras paleatus y Pimelodella laticeps (Pisces Siluriformes). Revista del Museo Argentina de Ciencias Naturales "Bernardino Rivadavia" (Hidrobiología) 7(2): 31-45.

González-Bergonzoni, I. 2011. Dieta de peces de agua dulce: efectos de factores climáticos y complejidad del hábitat. Montevideo: Universidad de la Republica, PEDECIBA, Tesis de Maestría. 67 pp.

Grosman, F., G. González, P. Sanzano \& D. Agüería. 2002. Alimentación, nichos tróficos y competencia interespecífica de peces de la laguna de Monte, Argentina. In: Actas del Congreso Iberoamericano Virtual de Acuicultura CIVA 2002, pp. 129140. Tandil (Argentina): Facultad de Ciencias Veterinarias, Universidad Nacional del Centro de la Provincia de Buenos Aires.

Grosman F. \& P. Sanzano. 2003. ¿El pejerrey puede causar cambios estructurales en un ecosistema? Biología Acuática 20: 37-44.

Haro, J.G., M.A. Bistoni \& M. Gutiérrez. 2001. Ecología alimentaria del bagre blanco Pimelodus albicans (Val.) (Pisces, Pimelodidae) en la cuenca de Mar Chiquita (Córdoba, Argentina). Boletín de la Academia Nacional de Ciencias 66: 25-39.

Hopp, U., G. Maier \& R. Bleher. 1997. Reproduction and adult longevity of five species of planktonic cyclopoid copepods reared on different diets: a comparative study. Freshwater Biology 38(2): 289-300.

Hued, A.C. \& M.A. Bistoni. 2007. Abundancia y distribución de la fauna íctica en la cuenca del río Suquía (Córdoba, Argentina). Iheringia, Série. Zoologia 97(3): 286-292.

Jeppesen, E., M. Søndergaard, J.P. Jensen, K.E. Havens, O. Anneville, L. Carvalho, M.F. Coveney, R. Deneke, M.T. Dokulil, B. Foy, D. Gerdeaux, S.E. Hampton, S. Hilt, K. Kangur, J. Köhler, E.H.H.R. Lammens, T.L. Lauridsen, M. Manca, M.R. Miracle, B. Moss, P. Nõges, G. Persson, G. Phillips, R. Portielje, S. Romo, C.L. Schelske, D. Straile, I. Tatrai, E. Willén $\&$ M. Winder. 2005. Lake responses to reduced nutrient loading-an analysis of contemporary long term data from 35 case studies. Freshwater Biology 50(10): 1747-1771.

Jiménez-Badillo, M.L. \& M.R. Nepita-Villanueva. 2000. Espectro trófico de la tilapia Oreochromi saureus (Perciformes: Cichlidae) en la presa Infiernillo,
Michoacán-Guerrero, México. Revista de Biología Tropical 48(2/3): 487-494.

Kaisin, F.J. 1989. Dinámica, producción y balance energético del zoobentos en un embalse norpatagónico. Buenos Aires: Universidad Nacional de Buenos Aires, Tesis doctoral. $253 \mathrm{pp}$.

Krebs, C.J. 1989. Ecological methodology. University British Columbia:Harper Collins. 654 pp.

Lazzaro, X. 1997. Do the trophic cascade hypothesis and classical biomanipulation approaches apply to tropical lakes and reservoirs?Verhandlungen der InternationalenVereinigungfür Theoretische und Angewandte Limnologie 26: 719-730.

Lewis, W.M. 1976. Surface/volume ratio: implication for phytoplankton morphology. Science 192: 885-887.

López van Oosterom, M.V., C.S. Ocón, F. Brancolini, M.E. Maroñas, E.D. Sendra\& A. Rodrigues Capitulo. 2013. Trophic relationships between macroinvertebrates and fish in a pampean lowland stream (Argentina). Iheringia, Série Zoologia 103(1):57-65.

Lowe-McConnell, R.H. 1987. Ecological studies in tropical fish communities. London New York: Cambridge University Press.382 pp.

Macluf, C.C., M.C. Claps \& L.C. Solari. 1998. Plankton of an undisturbed plain's stream (Buenos Aires, Argentina). Verhandlungen Internationale Vereinigung für theoretische und angewandte Limnologie 26: 1057-1061

Marchese, M. 1984. Estudios limnológicos en una sección transversal del tramo medio del río Paraná. XI. Zoobentos. Revista de la Asociación de Ciencias Naturales del Litoral 15(2): 157-174.

Margalef, R. 1983. Limnología. Barcelona: Omega. $1010 \mathrm{pp}$.

Masdeu, M. 2011. Estructura trófica de las comunidades de peces de arroyos subtropicales y templados: implicancias de la dieta, el tamaño corporal y la temperatura. Montevideo: Universidad de la República, PEDECIBA, Tesis de Maestría. 93 pp.

Menni, R.C. 2004. Peces y ambientes en la Argentina continental. Monografías del Museo Argentino de Ciencias Naturales 5: 1-316.

Menni, R.C., H.L. López \&R.H. Arámburu. 1988. Ictiofauna de Sierra de la Ventana y Chasicó (provincia de Buenos Aires, Argentina) Zoogeografía y parámetros ambientales. Anales del Museo de Historia Natural de Valparaíso 19: 75-84.

Nomura, H., R. Pozzi \& F.A. Manreza. 1972. Caracteres merísticos e datos biológicos sôbreo mandí-amarelo, Pimelodus clarias (Bloch, 1782), do rio MogiGuaçu (Pisces, Pimelodidae). Revista Brasilera de Biologia 32: 1-14.

Odum, E.P. \& G.W. Barrett. 2005. Fundamentals of ecology. $5^{\text {th }}$ ed. Belmont, California:Thompson Brooks/Cole. 598 pp.

Oliveros, O.B. 1980. Campaña limnológica "Keratella I" en el río Paraná Medio: Aspectos tróficos de los peces de ambientes leníticos. Ecología Argentina 4: $115-126$

Pace, M.L., J.J. Cole, S.R. Carpenter \& J.F. Kitchell. 1999. Trophic cascades revealed in diverse eco- 
systems. Trends in Ecology \& Evolution 14(12): 483-488.

Paracampo, A. 2012. Toxicidad de pesticidas, ensambles de peces y su relación con las características limnológicas en arroyos Pampeanos. La Plata: Facultad de Ciencias Naturales Universidad Nacional de La Plata.Tesis doctoral. $174 \mathrm{pp}$.

Pennak, R.W. 1966. Structure of zooplankton populations in the littoral macrophyte zone of some Colorado lakes. Transactions of the American Microscopical Society 85: 329-349.

Pinkas, L., M.S. Oliphant \& Z.L. Iverson. 1971. Food habits of albacore blue-fin tuna and bonito in California waters. Fishery Bulletin 152: 1-105.

Reid, J.W. 1985. Chave de identicação e lista de referências bibliográficas para as espécies continentais sulamericanas de vida livre da ordem Cyclopoida (Crustacea, Copepoda). Boletim Zoologia, Universidade de São Paulo 9: 17-143.

Reynolds, C.S. 1984. The ecology of freshwater phytoplankton. London: Cambridge University Press. $384 \mathrm{pp}$.

Ringuelet, R.A. 1961. Rasgos fundamentales de la zoogeografía Argentina. Physis 22: 151-170

Ringuelet, R.A. 1975. Zoogeografía y ecología de los peces de aguas continentales de la Argentina y consideraciones sobre las áreas ictiológicas de América del Sur. Ecosur 2(3):1-122.

Ringuelet, R.A., R.H. Arámburu \& A.A. Arámburu. 1967. Los peces argentinos de agua dulce. La Plata: Comisión de Investigaciones Científicas Provincia de Buenos Aires. 602 pp.

Sampóns, M.R. 1988. Zoobentos del río Arrecifes (Buenos Aires, Argentina) y sus principales tributarios. Iheringia, Série Zoologia 68: 63-82.

Saul, W.G. 1975. An ecological study of fishes at a site in upper Amazonian Ecuador.Proceedings of the Academy of Natural Sciences of Philadelphia 127: 93-134.

Sokal, R.R. \& F.J. Rohlf. 1979. Biometría. Principios y métodos estadísticos en la investigación biológica. Madrid:Blume. 832 pp.

Teixeira-de Mello, F., M. Meerhoff, Z. Pekcan-Hekim\& E. Jeppesen. 2009. Substantial differences in littoral fish community structure and dynamics in subtropical and temperates hallow lakes. Freshwater Biology 54: 1202-1215.

Townsend, C.R. \& I.J. Winfield. 1985. The application of optimal foraging theory to feeding behaviour in fish. Pp. 67-98 in: Calow, P. \& P. Tytler (eds.). Fish energetics-Anew look. London: Croom Helm. 349 pp.

Uieda, V.S. 1983. Regime alimentar, distribuiçãoespacial e temporal de peixes (Teleostei) en um riacho naregião da Limeira, São Paulo. Campinas: Unicamp. Dissertaçãode Mestrado. 151 pp.

Wetzel, R.G. \& G.E. Likens. 1991. Limnological analyses. $2^{\text {nd }}$ ed. New York: Springer. $391 \mathrm{pp}$.

Winemiller, K.O. 1990. Spatial and temporal variation in tropical fish trophic networks. Ecological Monographs 60(3): 331-367.

Wolf, M., U. Matthias \& G. Roldan. 1988. Estudio del desarrollo de los insectos acuáticos, su emergencia y ecología en tres ecosistemas diferentes en el departamento de Antioquia. Actualidades Biológicas 17(63): 2-27.

Wootton, R.J. 1998. Ecology of teleost fishes. $2^{\text {nd }}$ ed. Dordrecht: Kluger. 386 pp.

Zavala-Camin, L.A. 1996. Introdução aos estudos sobre alimentação natural empeixes. Maringá: EDUEM. $129 \mathrm{pp}$.

Doi: 10.22179/REVMACN.19.519

Recibido: 6-VI-2017

Aceptado: 26-IX-2017 
